УДК $34 ; 342.6$

DOI https://doi.org/10.32844/2618-1258.2019.5-1.29

ЖУРАВЕЛЬ Я.В.

\title{
СУЧАСНА СИСТЕМА ТА СТРУКТУРА ОРГАНІВ ВИКОНАВЧОЇ ВЛАДИ УКРАЇНИ
}

У статті висвітлені питання діючої системи та структури органів виконавчої влади України, зазначено розподіл іiї на суб'єкт управління (керуючу систему) та об'єкт управління (керовану систему), визначено всю сукупність різноманітних зв'язків, які при цьому виникають. Надано загальну характеристику системи органів виконавчої влади в Україні з акцентуванням уваги на ії складники та елементарні частки. Звернута увага на соціальні, політичні та правові ознаки системи у вигляді іï абстрактної, спрощеної моделі та окремих елементів.

Зазначено, що вищим органом у системі органів виконавчої влади є Кабінет Міністрів України. Структурною ланкою виконавчої вертикалі $є$ центральні органи виконавчої влади, до складу яких входять міністерства, державні комітети (державні служби) зі спеціальним статусом.

Наголошено, що система органів виконавчої влади передбачає необхідність формування дієвої вертикалі виконавчої влади, яка б забезпечувала належну реалізацію законодавчо визначених політичною системою цілей і владних рішень зверху донизу. 3'ясовано, що особливістю виконавчої влади як гілки державної влади $€$ те, що вона має виконавчий і розпорядчий характер та забезпечує практичну організацію виконання законодавчих і нормативних актів. Діяльність системи органів виконавчої влади розкривається у розділі VI Конституції України «Кабінет Міністрів України. Інші органи виконавчої влади», де обгрунтовано об'єднуються усі ієрархічні рівні органів виконавчої влади - вищий, центральний, місцевий.

Вказано, що реформаторські процеси, які відбуваються в економічній, соціальній і політичній сферах суспільного життя, сьогодні висувають підвищені вимоги до системи та структури органів виконавчої влади щодо вироблення дієвих механізмів управління розвитком територіальних громад.

Ключові слова: органи виконавчої влади, дечентралізація влади, Кабінет Міністрів України, соиіальна система, структура, форма громадського устрою, управління.

The author of the article has highlighted the issues of the current system and structure of executive authorities of Ukraine; has proved its division into the subject of management (managing system) and the object of management (managed system); has defined the entire set of various relationships that arise. The author has provided the general characteristics of the system of executive authorities in Ukraine, emphasizing on its constituent and elementary parts. Particular attention has been paid to the social, political and legal features of the system in the form of its abstract, simplified model and individual elements.

It has been proved that the highest agency in the system of executive authorities is the Cabinet of Ministers of Ukraine. The structural link of the executive vertical is the central agencies of executive power, which include ministries, state committees (public services) with special status.

It has been emphasized that the system of executive authorities presupposes the necessity of forming an effective vertical of executive power, which would ensure the proper implementation of the goals and power decisions, defined by the political system, from the top down. It has been clarified that the peculiarity of the executive power as the branch of government is the fact that it has executive and administrative character and ensures practical organization of implementing legislative and regulatory acts. The ac-

(C) ЖУРАВЕЛЬ Я.В. - кандидат юридичних наук, доцент, декан юридичного факультету (Академія праці, соціальних відносин і туризму) 
tivity of the system of executive authorities has been revealed in the Section VI of the Constitution of Ukraine "Cabinet of Ministers of Ukraine. Other Executive Agencies", where all hierarchical levels of executive authorities - the highest, central, local - are reasonably combined.

It has been stated that the reform processes that take place in the economic, social and political spheres of public life, nowadays pose increased demands to the system and structure of executive authorities in regard to developing effective mechanisms for managing the development of territorial communities.

Key words: executive authorities, decentralization of power, Cabinet of Ministers of Ukraine, social system, structure, form of social structure, management.

Вступ. Впровадження реформ та обговорення перспектив розвитку територіальних громад у контексті децентралізації є основною метою України на шляху до втілення в державі європейських стандартів. Комплекс заходів та реформ з децентралізації влади в Україні розпочався у 2014-му році. Неможливо приступати до втілення чогось нового, не дослідивши досвід минулих помилок, поразок, негараздів, адже вихідним положенням для вивчення предмета дослідження $\epsilon$ об'єктивні реалії сьогодення, а саме шлях до децентралізації влади. Цим саме й зумовлена проблематика дослідження.

Аналіз останніх досліджень і публікацій. Дослідженню системи та структури органів виконавчої влади в Україні присвячені праці В.Л. Ортинського, 3.Р. Кісіль, М.В. Ковалів («Управління в органах виконавчої влади України», 2008 р.), О.Ф. Андрійка, Ю.П. Битяка, Н.В. Кізіма, В.Л. Коваленка («Виконавча влада і адміністративне право», 2002 р.), Ю.В. Ковбасюка, К.О. Ващенка, В.В. Толкованова («Місцеве самоврядування в Україні: сучасний стан та основні напрями модернізації», 2014 р.), В.Г. Сисоєвої («Актуальні питання взаємодії органів місцевого самоврядування та місцевих державних адміністрацій», 2012 р.) та інших вітчизняних учених, здобутки яких дозволили сформулювати низку авторських визначень та пропозицій, що мають науко-практичне значення у досліджуваній сфері.

Однак з урахуванням змін у чинному законодавстві України проблеми сучасної системи та структури органів виконавчої влади України останнім часом не досліджувалися. Тому вважаємо, що запропонована тема потребує подальшої поглибленої розробки та висвітлення.

Постановка завдання. Мета статті - дослідити діючу систему та структуру органів виконавчої влади України та визначити подальші можливості ії трансформації в процесі децентралізації влади.

Результати дослідження. Конституційні засади побудови структури органів виконавчої влади визначені в Основному Законі України, а саме в розділі VI «Кабінет Міністрів України, інші органи виконавчої влади», де в ст. 113 закріплено, що Кабінет Міністрів України (далі - КМУ) $є$ вищим органом у системі органів виконавчої влади [1, с. 34]. Розпорядженням КМУ «Про схвалення Концепції реформування місцевого самоврядування та територіальної організації влади в Україні» від 01.04.2014 № 333-р [2] схвалено Концепцію реформування місцевого самоврядування та територіальної організації влади в Україні, в якій зазначено, що система місцевого самоврядування сьогодні не задовольняє потреб суспільства. Функціонування органів місцевого самоврядування у більшості територіальних громад не забезпечує створення та підтримку сприятливого життєвого середовища, необхідного для всебічного розвитку людини, її самореалізації, захисту іiі прав, надання населенню органами місцевого самоврядування, утвореними ними установами та організаціями високоякісних і доступних адміністративних, соціальних та інших послуг на відповідних територіях [3].

Для того щоб визначити загальну характеристику системи органів виконавчої влади в Україні, насамперед необхідно розуміти, що таке взагалі система та які їі складники. В науковій літературі $\epsilon$ різні думки щодо тлумачення поняття «система». Так, у Великому тлумачному словнику сучасної української мови: зазначено, що система - це: 1 . Порядок, зумовлений правильним, планомірним розташуванням і взаємним зв'язком частин чого-небудь. Заведений, прийнятий порядок; 2. Форма організації, будова чого-небудь (державних, політичних, господарських організацій, установ). Форма суспільного устрою; формація. 3. Сукупність яких-небудь елементів, одиниць, частин, об'єднуваних за спільною ознакою, призначенням [4, с. 1320].

Натомість соціальна система - це складно-організоване цілісне утворення, впорядковане і пов' язане із сукупністю взаємодетермінованих зв'язків між його елементами. Можна виділити ряд особливостей, притаманних соціальній системі: 1) цілісність, відносна завершеність об'єкта 
і його відносна єдність; 2) наявність внутрішніх зв'язків; 3) наявність зовнішніх зв'язків з іншими об'єктами та системами; 4) наявність власної структури, внутрішньої будови; 5) як об'єкт $\epsilon$ відносно автономною; 6) самоорганізована і саморегульована система; 7) виконує численні функції; 8) скерована на досягнення певного результату. Сучасне суспільство - це система, яка складається з окремих рівнів соціальних спільностей [5].

Різні політичні явища в суспільстві об'єднані поняттям «політична система» суспільства. Система - це одне з основних понять політології, яке дає змогу скласти уявлення про суспільство у вигляді його абстрактної, спрощеної моделі чи окремих елементів. Це поняття запозичене 3 електроніки й кібернетики американськими вченими Г. Алмондом, Д. Істоном, В. Мітчелем, які вважали його універсальною категорією наукового аналізу, яка охоплює певну кількість взаємопов'язаних елементів, що утворюють стійку цілісність, мають певні інтегративні особливості, притаманні саме цій спільноті, дотичних до вироблення політичних рішень. Призначення політичної системи - це забезпечення інтеграції, розробка та реалізація загальної мети суспільства [6].

Система державного управління органічно поєднує у своєму складі: суб'єкт управління (керуючу систему); об'єкт управління (керовану систему); всю сукупність різноманітних зв'язків, які при цьому здійснюються (систему управлінських відносин щодо їх взаємодії). Для розкриття суті діяльності об'єкта управління необхідно застосовувати взаємопов'язаний комплекс різних моделей управління. Виявлення (створення) ієрархії підсистем у великій системі дозволяє додатково вивчити як властивості системи загалом, так і іiі компонентів зокрема. Розмір великої системи може бути визначений за різними критеріями: кількість підсистем: (апріорних - теоретичних, за законом; апостеріорних - фактичних - на практиці); кількість рівнів ієрархічних підсистем, яка відповідає кількості «прирощувань» метамови, що описує властивості нового рівня за допомогою понятійного апарату попереднього рівня [7, с. 515].

3 огляду на це програма чи план будь-якого ієрархічного рівня мають базуватися на чітко визначеній цілі і прогнозі майбутніх подій, узгоджуватися з усіма зацікавленими системами, підсистемами і передбачати можливість координації під час їх виконання, формуватися з використанням чітких кількісних і якісних показників, що піддаються вимірюванню, передбачати стимулювання виконавців. Особливості функціонування системи державного управління виявляються в тому, що на кожному ієрархічному рівні має відбуватися планування діяльності і розвитку керованого об'єкта та колективу відповідного органу влади. Для КМУ - це довгострокові і короткострокові програми економічного і соціального розвитку України і плани діяльності Уряду, для галузі - програми і плани розвитку відповідних об'єктів та плани міністерств, для регіону - аналогічно стосовно господарського комплексу певної області або районів та колективів обласної та районної державної адміністрації [8, с. 431].

I врешті-решт визначення поняття системи в праві. Система права та система законодавства виступають як парні категорії, які входять до ширшої за обсягом системи правових явищ правової системи. Якщо структура системи права обмежується нормами, інститутами, підгалузями та галузями права, а система законодавства включає законодавчі масиви, то правова система охоплює всі правові явища, всю правову дійсність [9].

На думку Ю.С. Шемчушенка, правова система - це сукупність взаємопов'язаних між собою системи права та засобів іiі реалізації. Ця система має внутрішню ієрархічну структуру і взаємодіє з навколишнім середовищем. Засадничою основою розвитку правової системи України є правова політика держави. Вона стосується правозастосовної і правоохоронної діяльності. Стратегічні й тактичні аспекти цієї політики відображені в концепціях розвитку законодавства, юридичної освіти і науки, адміністративно-правової реформи, реформи правоохоронних органів України [10, с. 39].

Теорія держави і права до основних ознак права включає: системність, як цілісну систему взаємопов'язаних норм, де у кожної норми є своє строго визначене місце і взаємозв'язки з іншими нормами, та вираз міри свободи і справедливості, за якого право втілює основні права і свободи людини, надає людині легальну можливість реалізувати свої інтереси, не порушуючи права і свободи інших людей. Крім того, воно встановлює баланс між поведінкою людини і її соціальним станом (справедливість). У цьому полягає особистісна цінність права [11, с. 45].

Таким чином, право - це система загальнообов'язкових, формально визначених, встановлених і охоронюваних державою правил поведінки, що регулюють суспільні відносини і виражають міру свободи і справедливості [11, с. 45].

У навчальному посібнику «Основи правознавства» за загальною редакцією професора О.В. Негодченка зазначено, що слово право - означає можливості, які має соціальний суб'єкт, 
сукупність (систему) особливих правил соціальної поведінки загального характеру, відповідність форм явища його сутності тощо. Серед усіх тлумачень терміна право найбільш важливим для юридичної науки $є$ такі його визначення, як: 1. Певні можливості, які має соціальний суб'єкт; 2. Система юридичних норм, з допомогою яких здійснюється регулювання суспільних відносин $[12$, c. 35$]$.

Крім вищезазначених систем, у науковій літературі розрізняють: управління в технічних системах (нежива природа - технічне управління), управління в біологічних системах (жива природа - біологічне управління), управління в соціальних системах (управління в суспільстві соціальне управління). Всі три види систем управління пов'язані між собою [13, с. 18].

На наш погляд, система (в загальному розумінні) повинна мати такі ознаки: 1 . Мати зв'язки з іншими системами, підсистемами; 2. Елементи системи мають бути взаємопов'язані; 3. Відносини життєдіяльності системи, підсистеми повинні бути координованими; 4. Система управлінських відносин повинна мати внутрішню ієрархічну структуру; 5. Зберігання орієнтації суб'єктів системи на її норми і цінності.

Інакше кажучи, система - це взаємозв'язок частин, елементів, одиниць, що об'єднані спільними ознаками для здійснення самоорганізації та самоуправління, в тому числі в процесі децентралізації влади. Таку самоорганізацію елементів сьогодні становить система органів виконавчої влади, яка, реалізуючи певну частину повноважень держави, виконує функції пов'язані з реалізацією положень Конституції держави, ії законів і інших нормативних актів.

Переходячи до вивчення загальної характеристики структури органів виконавчої влади в Україні, необхідно зазначити, що відповідно до ст. 6 Конституції України державна влада в Україні здійснюється на засадах її поділу на законодавчу, виконавчу та судову. Органи законодавчої, виконавчої та судової влади здійснюють свої повноваження у встановлених Основним Законом межах і відповідно до законів України [1].

Органи виконавчої влади в Україні здійснюють дві основні функції: виконавчу та розпорядчу. Виконавча функція полягає у тому, що ці органи безпосередньо виконують нормативні приписи та інші акти законодавчої влади. Розпорядча функція характеризується тим, що для виконання актів законодавчої влади органи виконавчої влади від свого імені видають управлінські акти, дають відповідні розпорядження. Органи виконавчої влади не приймають закони, як Верховна Рада, а забезпечують управління економікою, освітою, наукою, соціальною сферою, вирішують усі інші управлінські справи [14, с. 139].

Структура органів виконавчої влади в Україні включає структурні ланки трьох організаційно-правових рівнів. Вищим органом у системі виконавчої влади є КМУ - Уряд. Відповідно до статті 113 Конституції України КМУ відповідальний перед Президентом України та підконтрольний і підзвітний Верховній Раді України у межах, передбачених у статтях 85, 87 Конституції України [1].

КМУ у своїй діяльності керується Конституцією і законами України, актами Президента України. КМУ є вищим органом у системі органів виконавчої влади, який здійснює виконавчу владу безпосередньо, через центральні органи виконавчої влади, Раду міністрів Автономної Республіки Крим і місцеві державні адміністрації, спрямовує та координує діяльність цих органів. Він $є$ колегіальним органом і здійснює свої повноваження шляхом прийняття рішень на засіданнях. Свою діяльність КМУ планує на основі та на виконання Програми діяльності КМУ [15].

Підтвердженням статусу КМУ як вищого органу в системі органів виконавчої влади $\epsilon$ коло завдань, визначених у положеннях ст. 116 Конституції України, зокрема, йдеться про забезпечення державного суверенітету й економічної самостійності України, здійснення внутрішньої і зовнішньої політики держави; забезпечення проведення фінансової, цінової, інвестиційної та податкової політики, а також забезпечення політики в інших сферах суспільних відносин; організацію і забезпечення зовнішньоекономічної діяльності України, митної справи, спрямування i координацію роботи міністерств, інших органів виконавчої влади [1].

Відносини між виконавчою владою і, зокрема, КМУ і Президентом України регулюються ст. 106 Конституції України. Президент України призначає за згодою Верховної Ради України Прем'єр-міністра України, припиняє повноваження Прем'єр-міністра України та приймає рішення про його відставку [1]. Відповідно до п. 1 ст. 14 Закону України «Про Кабінет Міністрів України» Президент України має право прийняти рішення про відставку КМУ, тобто питання відповідальності КМУ перед Президентом України має політичний характер і може вирішуватися шляхом прийняття рішення про відставку. При цьому Прем'єр-міністр України зобов'язаний подати Президенту України заяву про відставку КМУ у день прийняття рішення Президентом України [16]. 
Одним із найважливіших завдань КМУ є забезпечення виконання законодавчих актів на всій території держави, систематичний моніторинг стану їх виконання та контроль за діяльністю органів виконавчої влади, за усуненням можливих порушень. Нормотворча діяльність КМУ має підзаконний характер і здійснюється відповідно до положень Конституції та законів України. Подання КМУ доповіді про хід виконання Державного бюджету України поточного року разом із проектом Державного бюджету України на наступний рік дає можливість Верховній Раді України проконтролювати фінансову ситуацію в державі та провести моніторинг діяльності уряду 3 метою уникнення ризиків, що супроводжували виконання бюджету поточного року [16].

Прем’єр-міністр України вносить Президенту України подання про призначення членів КМУ, у якому персональний склад КМУ може вноситися єдиним списком або можливе внесення подання окремо на кожну посаду члена КМУ разом з відомостями про особу, визначеними в п. 5 ст. 9 Закону України «Про Кабінет Міністрів України» [16]. Особа, що призначена членом КМУ, набуває повноважень за посадою з моменту видання Указу Президента України про призначення iii членом КМУ. Порядок формування складу КМУ дає підстави для висновку, що Прем'єр-міністр України пропонує кандидатури на посади першого віце-прем'єр-міністра України та віце-прем’єр-міністрів України, тоді як КМУ визначає розподіл повноважень.

Відповідно до Розпорядження КМУ «Про утворення комісій з проведення реорганізації та ліквідації деяких центральних органів виконавчої влади» від 06 вересня 2019 № 738-р. утворено: комісії з проведення реорганізації центральних органів виконавчої влади за переліком; комісії 3 проведення ліквідації центральних органів виконавчої влади за переліком [17].

Висновки. Таким чином, проаналізувавши систему та структуру органів виконавчої влади в Україні, можна дійти висновку, що КМУ - Уряд, дійсно має свою визначену систему та внутрішню ієрархічну структуру підпорядкованості. Реформаторські процеси, які втілюються в економічній, соціальній, політичній, правовій та в інших сферах суспільства, вимагають від системи органів виконавчої влади України вироблення дієвого механізму їх функціонування на засадах децентралізації влади та розвитку територіальних громад.

Вбачається, що існуючий адміністративно-територіальний розподіл України не відповідає вимогам сьогодення, оскільки створення територіальних громад (об'єднаних територіальних громад) переважно не має підтримки з боку широких верств населення, адже люди не розуміють сам процес децентралізації, а також стикаються із протидією з боку районних адміністрацій та місцевих рад. Тому назріла нагальна потреба замислитись над новим адміністративно-територіальним розподілом України, наприклад за географічним, демографічним або економічним принципами. Перспективним у подальшому є наукова розробка питань, пов'язаних з формуванням ефективної організації виконавчої влади в Україні.

\section{Список використаних джерел:}

1. Конституція України: Закон України від 28.06.1996 № 254к/96-BP. URL: http://zakon3.rada.gov.ua/laws/show/254к/96-вр (дата звернення 11.01.2020).

2. Про схвалення Концепції реформування місцевого самоврядування та територіальної організації влади в Україні: розпорядження Кабінету Міністрів України від 01.04.2014 № 333 -р. URL: https://zakon.rada.gov.ua/laws/show/333-2014-\%D1\%80\#n8 (дата звернення 12.01.2020).

3. Концепція реформування місцевого самоврядування та територіальної організації влади в Україні. URL: https://zakon.rada.gov.ua/laws/show/333-2014-\%D1\%80\#n8 (дата звернення 13.03.2020).

4. Великий тлумачний словник сучасної української мови: 250000 / уклад. та голов. ред. В.Т. Бусел. Київ ; Ірпінь : Перун, 2005. VIII, 1728 с.

5. Соціологія: навчальний посібник / Герасимчук А.А., Палеха Ю.І., Шиян О.М. Київ : Вид-во Свропейського університету. 2004. 246 с.

6. Політологія: курс лекцій. 2004. 236 с. URL: http://politics.ellib.org.ua/pages-2861.html (дата звернення 05.03.2020).

7. Енциклопедія державного управління: у 8 т. / Нац. акад. держ. упр. при Президентові України; наук.-ред. Колегія : Ю.В. Ковбасюк (голова) та ін. Київ : НАДУ, 2011. Т. 1: Теорія державного управління / наук.-ред. Колегія : В.М. Князєв (співголова), І.В. Розпутенко (співголова) та ін. 2011. 748 с.

8. Державне управління : підручник : у 2 т. / Нац. акад. держ. упр. при Президентові України ; ред. кол.: Ю.В. Ковбасюк (голова), К.О. Ващенко (заст. голови), Ю.П. Сурмін (заст. голови) та ін. Київ ; Дніпропетровськ : НАДУ, 2012. Т. 1. 564 с. 
9. Баранов В.М., Поленина С.В. Система права, система законодательства и правовая система. Н. Новгород, 1999. 46 с.

10. Юридична енциклопедія: В 6 т. / редкол.: Ю.С. Шемчушенко (гол. редкол.) та ін. Київ : Укр. Енцикл., 1998. Т. 5: П-С. 2003. 736 с.

11. Основи правознавства України : навчальний посібник. Вид. 6 / Ківалов С.В., Мизиченко П.П., Крестовська Н.М., Крижанівський А.Ф. Харків : Одісей, 2006. 358 с.

12. Основи правознавства : навч. посібник. 8-е вид. доп. і перероб / кер. авт. кол. О.В. Негодченко. Київ : Центр навчальної літератури, 2005. 416 с.

13. Ортинський В.Л., Кісіль 3.Р., Ковалів М.В. Управління в органах виконавчої влади України. Навч. пос. Київ : Центр учбової літератури. 2008. 296 с.

14. Основи правознавства : навч. посіб. / В.П. Пастухов, В.Ф. Пеньківський, В.П. Капелюшний, О.В. Ришкова, за заг. ред. проф. В.П. Пастухова. Київ : Школа, 2003. 380 с.

15. Про затвердження Програми діяльності Кабінету Міністрів України: постанова Кабінету Міністрів України від 29.09.2019 № 849. URL: https://www.kmu.gov.ua/npas/pro-zatverdzhennyaprogrami-diyalnosti-kabinetu-ministriv-ukrayini-849290919 (дата звернення 05.03.2020).

16. Про Кабінет Міністрів України: Закон України від 27.02.2014 № 794-VII. URL: https://zakon.rada.gov.ua/laws/show/794-18 (дата звернення 05.03.2020).

17. Про утворення комісій з проведення реорганізації та ліквідації деяких центральних органів виконавчої влади: розпорядження Кабінету Міністрів України від 06.09.2019 № 738-р. URL: https://www.kmu.gov.ua/npas/pro-utvorennya-komisij-z-provedenny-a060919 (дата звернення 05.03.2020).

УДК 342.951: 346.21/346.9

DOI https://doi.org/10.32844/2618-1258.2019.5-1.30

ЗАМРИГА А.В.

\section{ДИФЕРЕНЦЮЮВАННЯ ТА МОДИФІКАЦЇ̈ КОНТРОЛЬНО-НАГЛЯДОВОЇ ДІЯЛЬНОСТІ ПУБЛІЧНОӤ АДМІНІСТРАЦЇ̈ ЩОДО ЗАБЕЗПЕЧЕННЯ ГОСПОДАРСЬКОЇ ДІЯЛЬНОСТІ В УКРАЇНІ}

У статті проаналізовано сучасний стан контрольно-наглядової діяльності в сфері адміністративно-правового забезпечення господарської діяльності в України. Вбачається, що він $є$ незадовільним та потребує нагальних модифікацій, зокрема, в частині перегляду доктрини та практики реалізації контрольно-наглядового провадження, де окремо існує наглядова діяльність та контролююча з усіма властивими їм характеристиками. Доведено, що контрольне провадження має бути санкціоноване саме судовими органами (адміністративно юрисдикційними), де виконавча влада повинна мати повноваження реалізації конкретного рішення (проведення перевірки), яке видане першим на основі матеріалів моніторингу діяльності суб'єкта господарювання, в процесі якого виявлено ознаки протиправності. Перевірка має проводитись щодо того кола питань та шляхом здійснення тих заходів контролю, які будуть зазначені у відповідному судовому рішенні. Наголошено, що відносини контролю у сфері господарської діяльності - це відносини між Урядом України в особі його органів, що здійснюють управління в сфері господарювання, та підконтрольними йому господарюючими суб'єктами. Державні органи в цьому разі виступають як учасники господарських відносин, що здійснюють господарсько-організаційну функцію держави. Водночас будь-який контролюючий державний орган $\epsilon$ адміністративним органом, відповідно, методи, які він застосовує, регулюються адміністративним правом. Отже, природа таких відносин має подвійний характер.

(C) ЗАМРИГА А.В. - кандидат економічних наук, докторант (Науково-дослідний інститут публічного права) 